\title{
opiniães
}

\section{drummond: uma poética entre e por aporias}

Drummond: a poetic between and by aporias

\section{Elisa Domingues Coelho*}

Mestra em Teoria e Crítica Literária (IEL/UNICAMP). Doutoranda no Programa de Pós-Graduação em Estudos Literários (FCLAr/UNESP). E-mail: elisadcoelho@gmail.com.

\section{Resumo}

A busca pela poesia que escapa à escrita, tema de tantos poemas de Carlos Drummond de Andrade, revela não ser apenas um tema transversal de sua obra, mas o princípio de funcionamento da mesma, que se cria labirinticamente a partir da reflexão sobre o caos moderno. Sua poética, portanto, não é uma lírica do cotidiano, que retira do mais ordinário acontecimento a poesia da vida, como a de Manuel Bandeira, ela vive da incompreensão e da aparente insolubilidade do presente caótico e desumano. A partir da análise feita por Antonio Candido em "Inquietudes na Poesia de Drummond" e Davi Arrigucci Júnior em Coração Partido, vemos como a obra do poeta se movimenta entre os impasses da própria literatura no mundo 
moderno. Se é a expressão da sua incompreensão e perplexidade diante dos acontecimentos, é também uma preocupação de responder ao tempo presente, como expresso por Mário de Andrade em "O movimento modernista". É, então, uma lírica que se cria tal qual o "Áporo", debatendo-se entre impasses, fazendo do bloqueio seu princípio poético e é na insolubilidade, na ausência de qualquer esperança, que o inseto se metamorfoseia em flor e o caos se faz poesia.

\section{Palavras-chave}

Literatura Brasileira; Modernismo; Poesia; Carlos Drummond de Andrade

\section{Abstract}

The pursuit of poetry that escapes writing, Carlos Drummond de Andrade's motif of many poems, discloses not only a transversal theme of his work, but also its own engine, which works by means of reflection on the modern chaos. Therefore, his poetics is not just about a day-to-day lyric, which takes out poetry from ordinary life events, like Manuel Bandeira's poems, it lives by incomprehension and the apparent insolubility of chaotic and inhumane of his period. Considering Antonio Candido analysis in "Inquietudes na Poesia de Drummond" and Davi Arrigucci Júnior in Coração Partido, we realize how the poet's work oscillates between the impasses of literature itself in the modern world. If it is the expression of his incomprehension and perplexity in the face of events, it is also a concern to respond to the present time, according to Mário de Andrade in "Movimento Modernista". It is a kind of lyric just like the poem "Áporo", convulsing between the impasses, that hurdles its poetic principle. And is in in the insolubility, in the absence of any hope that the insect metamorphoses itself into a flower and poetry arises from chaos.

\section{Keywords}

Brazilian Literature; Modernism; Poetry; Carlos Drummond de Andrade

\section{Procura da poesia: uma encruzilhada poética}

"Gastei uma hora pensando em um verso/ que a pena não quer escrever." (DRUMMOND, 2002, p. 40), assimse inicia "Poesia", poema curto que compõe sua primeira obra poética, Alguma Poesia (1930), e parece sintetizar a escrita drummondiana como esse trabalho labiríntico com as palavras. No entanto, se é tema tão comum em seus poemas, trata-se também de sua própria lírica, uma vez que se caracteriza como condição basilar de sua escrita e é, por isso, uma presença incessante que se revela um dos temas transversais de sua obra e um dos pilares de seu fazer poético.

Esse dilema da escrita do poeta, que aparece logo nesses dois primeiros versos, é, portanto, não só a grande questão desse poema em particular, como também da própria obra de Drummond. Quando não nos deparamos com um meta-poema como esse, parece estar a sua própria poética sempre marcada por esse movimento de encruzilhada, entre a reflexão sobre o mundo e essa luta para fazer, desse pensamento, escrita.

\section{Paralelos e entrecruzamentos possíveis}

Sobre esse aspecto, Davi Arrigucci Júnior (2002) ressalta, em Coração Partido, que a lírica drummondiana se faz justamente da fórmula, muito presente entre os poetas românticos, do "adensamento do lirismo pelo 
esforço meditativo" (ARRIGUCCl, 2002, p. 16). Esse paralelo deixa um certo incômodo, mas também um questionamento de como seria possível contrastar o mesmo processo de tessitura lírica em contextos literários tão distintos e, por isso mesmo, mostrase interessante aqui para pensar o que aparece reflexivamente intensificado nessas poéticas que torna possivel essa comparação.

Sabemos que a reflexão romântica era centrada numa subjetividade calcada no anseio pelo livre sentir e expressão de seus ideais; essa era uma resposta direta a um mundo burguês em ascensão que impunha normas e condutas, as quais oprimiam essa subjetividade. A reflexão sobre esse conflito - ou, melhor dizendo, esse soterramento -, em uma fórmula simples, não poderia resultar em outra coisa que não a vazão para uma expressão desse eu e toda sua filosofia contrária ao apregoado pela sociedade. Pensar como se dá esse processo na poesia de Drummond, um poeta da modernidade, é a questão que se coloca com essa aproximação feita por Arrigucci.

Se esse processo reflexivo e a expressão lírica advinda dele, assim como nos poetas românticos, está atrelada a seu tempo, precisamos olhar para o contexto moderno para entender se essa aproximação é realmente possível. $O$ que o paralelismo desses contextos históricos revela é que, mesmo em diferentes constructos, ambos têm em comum a configuração de um momento em que o eu lírico se encontra frente a uma sociedade em transformação.

Assim sendo, a modernidade que se apresenta para Drummond é um tempo de mudanças profundas que conformam um presente menos coeso, multifacetado porque permeado pelos conflitos e desigualdades sociais, entreguerras e consolidação dos regimes totalitários. Ao invés do conflito eu/mundo, há um eu que observa um mundo muito menos orgânico, cuja ebulição de conflitos em velocidade assustadora deixa o sujeito atônito, de modo que não há um ideal a ser apregoado, como no romantismo, pois o caos da vida perde a tudo e a todos. A grande questão é pensar como se dará esse adensamento reflexivo na sua lírica diante de uma sociedade tão caótica. Olhemos a última estrofe de "Acordar, Viver":

\author{
Como proteger-me das feridas \\ que rasga em mim o acontecimento, \\ qualquer acontecimento \\ que lembra a Terra e sua púrpura \\ demente? \\ E mais aquela ferida que me inflijo \\ a cada hora, algoz \\ do inocente que não sou?
}

(ANDRADE, 2007, p. 21)

Esses versos integram Farewell (1996), obra publicada postumamente que se configura como uma "espécie de prestação de contas de sua vida literária, através das temáticas recorrentes em sua poética, sobretudo, a morte, uma retrospectiva de sua gaucherie" (SILVA, 2018, p. 2). Por isso mesmo, figuram como uma significativa confissão desse eu, em uma voz lírica já madura e transpassada pelo caos da modernidade, não sendo mais possível identificar um eu em clara intenção de dissociação e recusa da sociedade, de modo a delinear um antagonismo bem definido.

Assim sendo, podemos dizer que, se há um mesmo procedimento estético que pode ser reconhecido nos poetas românticos e em Drummond, ele perde aquele contorno do antigo conflito, em que há um eu e um outro bem delimitados, para ser tocado e fragmentado por esse outro - o caos moderno -, pois todos os acontecimentos que observa e vive alastram essa marca do conflito em si e confluem para uma subjetividade inundada pela inquietude e desamparo. 
Nesse aspecto, é interessante pensar em como a poesia se faz dessa relação com os acontecimentos: são eles, desde os mais ordinários, sua faísca inicial e, a princípio, poderíamos pensar ser o corriqueiro da vida sua matéria poética. Para pensar nisso, olhemos para um outro poeta cuja poesia se faz igualmente do cotidiano, Manuel Bandeira.

\begin{abstract}
A força poética de Drummond vem um pouco dessa falta de naturalidade, que distingue a sua obra, por exemplo, da de Manuel Bandeira. O modo espontâneo com que este fala de si, dos seus hábitos, amores, família, amigos, transformando qualquer assunto em poesia pelo simples fato de tocá-lo, talvez fosse uma aspiração profunda de Drummond, para quem o eu é uma espécie de pecado poético inevitável, em que precisa incorrer para criar, mas que o horroriza à medida que 0 atrai. [...] (CANDIDO, 2011, p. 71).
\end{abstract}

Essa diferença entre os dois poetas, a que Candido chama atenção, torna necessário repensar a relação entre a vida e a lírica drummondiana. Bandeira aparece aqui como exemplo, que se contrapõe ao elucidar esse funcionamento de buscar sua poesia em todas as mais sutis pequenezas da vida. Parece até ser dele que Drummond fala em Pau Brasil (1986, p. 57) "Se eu gosto de poesia? Gosto de gente, bichos, plantas, lugares, chocolate, vinho, papos amenos, amizade, amor. Acho que a poesia está contida nisso tudo.", afinal, como Candido também ressalta, talvez fosse essa uma aspiração do nosso poeta, mas não é a relação que ele estabelece em sua lírica.

Esse contraste com a poesia de Bandeira coloca a questão da relação entre os acontecimentos e a poética drummondiana em outros termos e nos faz pensar que, por Bandeira ter essa escrita que trata com naturalidade o cotidiano, pode se falar que o corriqueiro da vida é sua matéria poética, mas o mesmo não se aplica a Drummond. Tendo sido, de fato, sua aspiração ou não, o que se percebe é que sua poesia não carrega nada de natural ou espontâneo.

Isso porque o fundamento básico de sua poética é esse quebra-cabeça entre a reflexão e a expressão: sua lírica se move labirinticamente entre o impasse subjetivo que todos os acontecimentos desencadeiam e o impulso irrefreável para a escrita que, no entanto, escapa à sua vontade. Por isso o material de sua poesia não é o acontecimento em si, mas justamente o seu lastro no eu lírico, essa relação do eu poético com a vida ou ainda, melhor dizendo, é esse "rasgar na alma".

[...] A poesia é o assalto do acontecimento; não o dos jornais, bem entendido, mas o acontecimento verdadeiramente humano: a revelação súbita das violências da vida, ou pelo menos do sentido oculto de seu curso "normal". [...] (MERQUIOR, 1975, p. 49)

Portanto, se é verdade que Drummond queria fazer originariamente a poesia simples dos acontecimentos, não pôde, no entanto, chegar até eles, pois, como afirma Merquior, foi, antes, tomado de assalto. Ao tocálos, o que eles lhe revelam mergulha seu fazer poético na impossibilidade de escapar à incompreensão - e à perplexidade - dessa multiplicidade do caos pós-guerra do mundo moderno. Como parte desse movimento reflexivo, o último verso "do inocente que não sou?" parece ser a manifestação lírica da culpa desse eu - manifestação-confissão de lírica derradeira de toda uma vida de alma partida pela modernidade -, enquanto "pecado poético inevitável", eu lírico inundado pela vida e por essa poesia, que recusa a sua pena e invade o poema: a poesia estaca no meio do caminho entre ele e o mundo e inunda tudo. 
A frustração e a confissão que avultam no poema demarcam essa culpa, advinda da consciência e desejo de versar sobre o tempo presente, porque "Para ele, a experiência da linguagem, por mais importante, por mais necessária que seja, é o meio, não o fim, do discurso literário." (MERQUIOR, 1975, p. 78). Se essa lucidez de Drummond coloca a lírica nessa complexa relação entre subjetividade e sociedade, traz, também, esse olhar para a primeira como uma espécie de lugar do pecado, que desvia a arte das questões sociais, o que nos lembra uma crise similar, manifesta por Mário de Andrade:

[...] O homem atravessa uma fase integralmente política da humanidade. Nunca jamais ele foi tão "momentâneo" como agora. Os abstencionismos e os valores eternos podem ficar para depois. E apesar da nossa atualidade, da nossa nacionalidade, da nossa universalidade, uma coisa não ajudamos verdadeiramente, duma coisa não participamos: o amelhoramento políticosocial do homem. E esta é a essência mesma da nossa idade [...] (ANDRADE, s/d., p. 255).

Esse sentimento que permeia a crítica do literato é simbólico de toda a geração de modernistas da Semana de 22, em particular aqueles que viviam a pesquisa estética que o Movimento Modernista proporcionou, mas que tinham seu olhar atento para os problemas "do tempo presente" e sentiam que a literatura tinha um dever perante o acirramento dos conflitos sociais. Sentimento esse que, se, na década seguinte, resultou em uma literatura mais engajada e, às vezes, até panfletária, também se transmutaria nesse desgosto e certa culpa por mergulhar na subjetividade.

No caso de Drummond, vemos a relação com a temática social como arremate desse emaranhado tão complexo que é seu pensamento e o sentimento desse compromisso, muitas vezes traído, compõe o seu "tocar o acontecimento". Afinal, não chegar a conseguir transformá-lo em sua matéria e recair nas feridas que ele causava em sua alma - sendo inundado pelo seu eu em conflito - é a essência de um certo desgosto recorrente em sua poética, expressão desse eu encalacrado, que não consegue uma saída nem para o mundo nem para si.

[...] O desejo de transformar o mundo, pois, é também uma esperança de promover a modificação do próprio ser, de encontrar uma desculpa para si mesmo. E talvez esta perspectiva de redenção simultânea explique a eficácia da poesia social de Drummond, na medida em que (Otto Maria Carpeaux já o disse faz tempo) ela é um movimento coeso do ser no mundo, não um assunto, mediante o qual um vê o outro. O seu cantar se torna realmente geral porque é, ao mesmo tempo, profundamente particular (CANDIDO, 2011, p. 83).

Dessa forma, o que aparece como um impasse na lírica drummondiana, uma vez que todas as tentativas parecem destinadas ao fracasso nessa impossibilidade de se transpor a subjetividade e cumprir a necessidade de seu tempo - de fazer dos acontecimentos sua matéria lírica - é, na verdade, a coerência interna que dá a essa poética sua grande força. É na angústia dessa subjetividade atormentada que olhar para social e para si se unem, já que, como afirma Candido, a maior coesão de sua obra está justamente nessa dependência entre a alma do poeta e seu tempo presente: do destino desses acontecimentos, que lhe afligem, depende o seu próprio. 


\section{A angústia do tempo presente}

Essa sua condição, de ser o poeta do estar no mundo, fez de sua poética grande expressão, no fim, do próprio drama humano, da busca por compreender e se compreender na trajetória da vida e da história. Afinal, se Drummond está constantemente se movimentando entre os impasses do caos moderno, é verdade também que nos diz muito mais sobre o caminho do que a possível chegada.

Seu princípio último de coerência, diante da ameaça do impasse, parece ser dado à primeira vista pela passagem de uma lógica conceptual para uma lógica do sensível, indo do pensamento ao mito. Mas a verdade é que a aporia é, no caso, menos não passagemabsoluta do que problema, menos errância infinita, produto sem saída da dúvida racional, do que experiência sofrida dos dramas concretos da existência para os quais não se tem resposta. [...] (ARRIGUCCl, 2002, p. 142).

Nos impasses da modernidade, habita a poesia de Drummond porque o poeta fez dela, justamente, a expressão dessa vivência labiríntica que, ao se mover de impasse em impasse sem nunca vislumbrar uma saída, optou por ali permanecer, e fez do próprio labirinto sua resposta. Desse modo, na imagem recorrente da impossibilidade de solucionar o problema que o cerca, a expressão lírica de toda uma vida repousa no falar da experiência de defrontar a insolubilidade dessas questões. Em diferentes atitudes, como todo ser que é vivo e que pulsa, o que persiste é essa essência de sua lírica: uma poética não dos acontecimentos, mas do caminho.

No meio do caminho tinha uma pedra tinha uma pedra no meio do caminho tinha uma pedra

no meio do caminho tinha uma pedra.
Nunca me esquecerei desse acontecimento na vida de minhas retinas tão fatigadas.

Nunca me esquecerei que no meio do

[caminho

tinha uma pedra

tinha uma pedra no meio do caminho

no meio do caminho tinha uma pedra

(ANDRADE, 2002, p. 36).

Esse poema, também componente do primeiro Drummond de Alguma Poesia, é, assim como "Poesia" o é do próprio fazer poético, emblemático do seu processo reflexivo, já que, logo na primeira estrofe, opera a construção estilística do "problema" que cerca o eu lírico, de modo que não só não há uma saída, como a repetição da mesma tentativa e mesma impossibilidade parece construir um círculo hermético que circunscreve seu caminho no bloqueio absoluto. Portanto, ao se ocupar exclusivamente dessa construção, utilizandose da repetição e organização sintática, multiplica essa pedra que cerca todos os caminhos possíveis e traz essa escolha poética de não tentar escapar ao obstáculo, ele apenas o expõe para nós.

A segunda estrofe nos revela que o que o poeta quer dizer ao leitor, aqui, nada tem a ver com a possibilidade ou não de superar a pedra que interrompe o caminho, uma vez que a superação não é uma questão nem na primeira nem na segunda estrofe. Essa última, ao trazer, como tema de sua reflexão final, a memória do bloqueio, intenta justamente o contrário, de modo que a matéria prima que cria o poema repousa na experiência, em transmitir o momento do bloqueio.

Dessa forma, o poema se consolida não como a lamentação ou desespero pela não passagem ou o esforço meditativo de tentar uma possibilidade de solução, o que lhe interessa é nos transmitir a existênغia dessa pedra no meio de seu caminho. Ao desenhar com 
as palavras esse estar frente ao bloqueio e ter por ele nossa trajetória modificada, o que o poeta nos diz é que essa é a única experiência definitiva da modernidade. É ela a experiência coletiva que se converte na nossa memória. A memória do impasse.

Outrossim, a reflexão que ele traz é, também, fazer, do drama humano dessa experiência, a sua expressão: "A poesia surge quando o universo se torna insólito, enigmático, embaraçoso - quando a vida já não é mais evidente. Neste sentido, a poética do primeiro Drummond é bem a peça de escândalo 'No meio do caminho' [...]" (MERQUIOR, 1975, p. 25). A partir da análise de Merquior, esse poema parece ser, então, essa ode do encontro labiríntico da reflexão da vida e da palavra, "No meio do caminho" e "Poesia" parecem se encontrar aqui - e não ao acaso são parte da primeira obra poética de Drummond - nesse desenho da coerência interna da lírica drummondiana, em que a poesia se faz desse encontro de bloqueios.

A exemplo desse encontro icônico, sua poética será atravessada por essa imagem do bloqueio, a tessitura difícil de sua lírica parece ser sempre de reconstruir estilisticamente, para nós, os caminhos e bloqueios que compõem esse labirinto que constrói sua relação com os acontecimentos.

Na verdade, a qualidade artística de sua obra depende do poder de articulação de que ele é capaz. Sua técnica de construção lida com materiais heterogêneos e divergentes, mas, ao mesmo tempo, com o mal-estar em face do mundo de onde os retira. Só assim salva a multiplicidade contraditória do mundo e da alma na unidade do poema, sem anular as diferenças, que constituem o pulso vivo das contradições, ou desconhecer o sem-fim das coisas que tendem a escapar ao desejo de totalidade quando se quer dar forma. [...] (ARRIGUCCl, 2002, p. 32).
Desse modo, esse será um procedimento fundante de sua poética, uma vez que não se restringe ao bloqueio enquanto simples temática, tampouco irá apenas atravessar transversalmente sua obra, mas essa tessitura labiríntica dos dilemas em que se encontra, fazendo do caminho e do impasse sua matéria, é o procedimento formal que caracteriza sua lírica.

Como afirmou Arrigucci, a poética drummondiana só se faz possível por essa habilidade de costurar tal qual uma colcha de retalhos o seu estar no mundo. Habilidade essa, de articulação dos conflitos sociais e humanos -, que aparece aqui como recurso estilístico fundante de sua obra. Em outras palavras, sua lírica se constitui desse trazer para a pena o impasse composto pelo encontro e desencontro das tantas contradições do mundo moderno a partir do seu próprio olhar multifacetado.

Quando nasci, um anjo torto desses que vivem na sombra disse: Vai, Carlos! ser gauche na vida.

As casas espiam os homens que correm atrás de mulheres.

A tarde talvez fosse azul, não houvesse tantos desejos.

O bonde passa cheio de pernas: pernas brancas pretas amarelas.

Para que tanta perna, meu Deus, pergunta

Porém meus olhos [meu coração.

não perguntam nada.

O homem atrás do bigode é sério, simples e forte. Quase não conversa.

Tem poucos, raros amigos o homem atrás dos óculos e do bigode. 
Meu Deus, por que me abandonaste se sabias que eu não era Deus se sabias que eu era fraco.

Mundo mundo vasto mundo, se eu me chamasse Raimundo seria uma rima, não seria uma solução. Mundo mundo vasto mundo, mais vasto é meu coração.

Eu não devia te dizer

mas essa lua

mas esse conhaque

botam a gente comovido como o diabo

(ANDRADE, 2002, p. 30).

Poucos poemas ilustram tão bem essa multiplicidade como o "Poema de Sete Faces", poema que abre seu livro Alguma Poesia, construída a partir de procedimento estético que Merquior (1975, p.11) definiu como "[...] equivalente literário de uma imagem cubista.", cada estrofe nos fala sobre uma reflexão do eu lírico, de modo que elas não se relacionam no sentido de compor uma grande questão. Em movimento contrário, elas têm o efeito de compor o fluxo de pensamento do eu que perambula pela cidade e nada compreende, pois nada parece se encaixar ao mesmo tempo em que tudo parece multiplicar as mesmas questões impenetráveis e insolúveis - e elas são tantas! - cada vez mais, que seguem se perpetuando, coabitando e constituindo o seu olhar perplexo diante da vida.

A impressão que a leitura nos dá, portanto, é esse acompanhar o poeta pela cidade e conhecer o fluxo de pensamentos que cada visão Ihe traz. A primeira estrofe nos lança no seu olhar de gauche para, em seguida, perder-nos nesse mundo incompreensível, de modo a compartilhar do seu estatuto de estranho no mundo. Assim como, nas três estrofes seguintes, observamos as casas, as mulheres, os homens, o bonde sem nada... A tudo observamos, tentamos compreender - enviesados pela perplexidade de quem nos guia - para, novamente, voltarmos para o eu, mergulhamos ainda mais no seu ser perdido e desolado e, ainda, retornamos mais uma vez ao mundo, sem, todavia, nada compreender, mas já compartilhando o consolo na comoção lírica, "[...] uma ação que se constrói por dentro da escuridão de um mundo tornado complexo e opaco." (BISCHOF, 2005. p. 137). É, portanto, por dentro da escuridão da perplexidade e incompreensão que, novamente, vivenciamos, pela lírica, a experiência do caminho.

Com esse procedimento, nós acompanhamos, através de sua poesia, os seus processos reflexivos, de forma que, como ele, terminamos sem uma síntese ou resolução. Com isso, compartilhamos a experiência humana do impasse e somos perpassados por essa tessitura múltipla, desencontrada e, através do olhar do eu lírico, compactuamos com seu drama de "estar no mundo" e o vivenciamos.

A dificuldade de todo esse processo se faz presente também como parte de seu procedimento estético, nunca construído para se passar por natural ou espontâneo. E, sempre na perspectiva dessa articulação dos conflitos do estar no mundo, é também fundante de seu fazer poético e nos coloca em outro processo labiríntico: a escrita. Isso porque a expressão drummondiana também tem essa característica de ser marcada pela luta, pelo trabalho árduo com as palavras que escapam à sua pena. Se voltarmos para "Poesia", já no $5^{\circ}$ e $6^{\circ}$ versos, poderemos elucidar essa dimensão estética: "Ele está cá dentro/ e não quer sair.".

O poema se inicia e retorna a esse movimento do pensamento que inunda a alma e o impele à escrita, mas as palavras são arredias e o jogam em mais esse bloqueio, quando ele se vê entre a incompreensão reflexiva e a resistência da linguagem. É esse 
entrecruzar que faz, do movimento de transformação da sua reflexão na lírica, o processo de lapidar a linguagem na dificuldade do bloqueio.

Em termos drummondianos, talvez se possa dizer que o sentimento é a marca que o mundo lavra na alma. A poesia, espécie de mineração, é uma arte de lavrar palavras: inscreve a marca do sentimento numa forma de linguagem. Por isso, ela traz em segredo, feito enigma, como uma cicatriz, algo do sentido do mundo que só sua forma pode conter e, de repente, revelar (ARRIGUCCI, 2002, p. 17).

Drummond se revela para nós, então, como esse poeta cuja expressão nunca pôde ser simples, já que sua poética é necessariamente muitas, porque vem ela desse quebra-cabeça de sua alma, marcada pela vida, que busca falar. Todavia, o caminho entre o sentir e o falar tem suas pedras e se reverte nesse trabalho atento e devoto de mineração para conseguir fazer, das marcas que a vida deixa dia após dia em sua subjetividade, sua própria marca-poema.

Esse segundo labirinto drummondiano a que chegamos repousa nesse outro caminho trilhado pelo poeta: fazer do encontro dos impasses reflexivo e expressivo a mineração das palavras e de si. Os impasses da incompreensão, em que o mundo lança o poeta, inserem-se, agora, nesse labirinto composto pelo movimento dialético do processo reflexivo e estético que se interpenetram e encurralam o poeta entre os bloqueios e desencontros, na busca de conseguir transformar o sentir em dizer.

Sendo assim, quando passamos a conhecer esse funcionamento aporético do pensamento do poeta, percebemos que seria, para ele, impossível que a expressão de sua trajetória reflexiva chegasse para nós de outra forma, com uma leveza mais próxima de Bandeira, talvez. A escrita de Drummond nada tem de acaso ou impensada ou, em uma questão anterior ainda, a sua busca não se encontra na vida e sim na perplexidade diante da mesma. Seria estranho, portanto, que sua lírica pudesse seguir um caminho que não revelasse um princípio poético outro que não esse fruto de um longo processo reflexivo e atormentado.

[...] De todo modo, resta a lição: a poesia drummondiana passa por um crivo de negatividade, até vir à luz, até constituirse em poema. O próprio acesso à matéria poética, em "Procura da poesia" - quando o poeta se aproxima do reino das palavras onde estão os poemas, em calma pura, em estado de dicionário - é, ao final, torcido [...]. (BISCHOF, 2005. P. 124)

Dito isso, o que podemos perceber é que, no enigma alimentado pelo desafio da escrita diante das questões do estar no mundo, essa expressão da mineração, transparente ao revelar seu trabalho sistemático e encalacrado, tem o papel fundamental de deixar, na lírica, as marcas dos caminhos percorridos nunca óbvios, sempre permeados pelo impasse e pela negatividade, em alguma instância, como bem afirmou Bischof -, sendo, portanto, a expressão o segundo labirinto drummondiano. Desse modo, como dito anteriormente, sua estilística será profundamente marcada por essa habilidade de articulação, o que constrói esse labirinto em seus poemas e faz deles terreno por onde o eu lírico percorre e trilha os caminhos do impasse. 


\section{A tessitura labiríntica: entre o pensamento e a linguagem}

Dessa maneira, a escrita se encontra com o pensamento nesse mesmo princípio fundamental: percebendo-se em uma existência entre vias sem saída aparente, a experiência que o poeta quer comunicar não é uma tentativa de se desvencilhar do bloqueio; ao contrário, o que merece ser narrado é a experiência humana do caminho bloqueado, pois é esse o drama fundamental da modernidade que precisa ser transformado em arte, é essa a função urgente da literatura naquele momento.

Ao contrário, ela é sempre objeto de uma procura, o produto de um esforço incessante, da luta com as palavras, que é um dos motivos recorrentes de sua obra e parece corresponder à sua concepção mais funda e dramática do poético: a poesia que é capaz de inundar uma vida inteira e resistir à pena que busca fixá-la num verso (ARRIGUCCl, 2002, p. 53).

Por isso, a luta com a escrita, assim como o olhar reflexivo do "estar no mundo", atravessará sua obra, tendo seu ápice em metapoemas como "Procura da Poesia". A única narrativa de que se ocupa o poema é esse caminho encalacrado da reflexão que precisa ser expressada, mas as palavras repousam também nesse complicado terreno da impossibilidade e, assim como o mundo foge à compreensão, a escrita foge a essa necessidade e toma o seu próprio curso. Dessa forma, a poesia que sairá será outra, não será prevista, será fruto impensável dessa situação labiríntica.

De forma análoga ao processo do pensamento drummondiano, que acompanhamos em textos como "Poema de Sete Faces", temos a escrita em "Poesia". Do $1^{\circ}$ ao $6^{\circ}$ verso, como já mostrado acima, acompanhamos esse caminho do poeta que tenta transformar o pensar em escrever e, quanto mais vivo se faz o pensamento, mais as palavras escapam à sua pena. Assim, tal qual compartilhamos o mesmo olhar que nada compreende do que observa do mundo e de si e termina sem nada além do mergulho na comoção lírica, agora também pegamos em sua mão e compartilhamos desse final, que não é chegada, é o caminho interrompido.

"Mas a poesia deste momento/ inunda minha vida inteira.", assim retornamos à narrativa do caminho cuja saída é o próprio bloqueio. A experiência, que é o objeto final da narrativa, que é história e vira a memória desse sujeito errante pelo mundo bloqueado, novamente é a pedra, a ausência da saída, a expressão que foge, pois é de viver a impossibilidade, novamente, que surge a poesia da vida inteira.

Assim, a reflexão surge como a condição para que o poeta alcance o que busca e, contraditoriamente, se torna o empecilho para isso. Este paradoxo, central à poética drummondiana, é expresso por diferentes modos, mas quase sempre o poeta se vê encalacrado em situações aporéticas, estrada de fato pedregosa a que teve de se afeiçoar desde a origem distante em Minas (ARRIGUCCl, 2002, p. 59).

Percebemos, assim, a poética de Drummond se constituindo nesse movimento entre os dois caminhos labirínticos que não só formam sua lírica como, ao fazê-lo, deixam suas marcas, assim como a vida o faz na alma do poeta. Sua poesia é a narrativa dos caminhos percorridos, ela traz o testemunho dessa experiência humana de sujeito e poeta e sua tessitura será necessariamente essa colcha de retalhos. Seguindo na mesma transparência, quer se mostrar como tal, não busca se passar por um só pano sem costura aparente, pois sua característica estilística mais fundamental é essa articulação que coloca lado a lado o vivido e o sentido 
sem esconder os percalços de sua existência, revelando uma reflexão sobre o próprio fazer poético: "[...] É por isso que ele pode inserir naturalmente o combate com as palavras, e a estada em seu reino, no quadro mais vasto de uma meditação sobre o sentido ético e humano da poesia. [...]" (MEROUIOR, 1975, p. 78).

Esse lugar do encontro dos caminhos percorridos em sua existência de eu-poeta - para o qual seu pensamento the impulsiona enquanto as palavras, em movimento contrário, repelem-no - mostra-se como uma situação aporética em que perguntas sem resposta e lutas sem vencedor se encontram e formam um círculo hermético. Essa trajetória de composição do procedimento da lírica drummondiana encontrará seu espelho e símbolo em um poema como o "Áporo".

\author{
Áporo \\ Um inseto cava \\ cava sem alarme \\ perfurando a terra \\ sem achar escape. \\ Que fazer, exausto, \\ em país bloqueado, \\ enlace de noite \\ raiz e minério? \\ Eis que o labirinto \\ (oh razão, mistério) \\ presto se desata: \\ em verde, sozinha, \\ antieuclidiana, \\ uma orquídea forma-se
}

(ANDRADE, 2012, p. 45). que esse poema compõe A Rosa do Povo (1945), como bem disse Pignatari (2004, p. 143): "[...] 'Áporo' surge na coletânea de um Drummond-ápice, $A$ Rosa do Povo (1945), ano da agonia do nazifascismo e do Estado Novo ("em país bloqueado"), ano da soltura de Luís Carlos Prestes ("presto se desata"...), ano de todas as auroras.". É, portanto, um Drummond já maduro, em plena feitura da poesia-acontecimento - e extremamente atento aos conflitos de seu tempo - que, na primeira estrofe, assim como em "No meio do caminho", narra esse esforço pela compreensão da vida e mineração das palavras, esse esforço constante e repetitivo entre a vida e a arte sem, contudo, achar uma solução nem para uma nem para outra.

O estado em que se encontra o inseto termina por traduzir o momento-emblema da experiência poética de Drummond: viver insistentemente o bloqueio. No entanto, o poeta se localiza em um esforço que, talvez, seja superior ao do nosso inseto, uma vez que é lúcido, consciente de sua escolha de subverter o labirinto e rodar e rodar, buscando, quem sabe, um Minotauro, mas nunca a saída, uma vez que sabe que ela não existe. Nesse sentido, afirma Bischof:

A dificuldade com que se debate o inseto está, no poema, potencializada. O espaço físico criado pelas imagens paradas é de tal modo opressivo, que temos a impressão de que se rompem, sob o peso da negatividade sem brechas, os limites entre a objetividade e o que é interior, entre o que acontece no espaço e que atinge, deste modo, um inseto que busca saída - e aquilo que sugere, mesclando-se à ação que ali toma corpo, algo da interioridade do sujeito, central à expressão lírica, e que talvez possamos ver espelhado neste inseto emparedado e confinado em um espaço fechado, sem solução. (BISCHOF, 2005. p. 51) 
Através de um domínio estilístico primoroso - como muito bem estudou Pignatari em seu consagrado ensaio "Um inseto semiótico" -, a situação de bloqueio se faz e se reforça na estética do poema assim como o tom opressivo da impossibilidade de escape, situação em que inseto e eu lírico se convergem. A segunda estrofe, todavia, dá ao leitor outra dimensão da situação aporética em que o poeta se colocou ao trazer essa constituição combinatória de um momento que une a exaustão e o bloqueio. Bloqueio esse em uma mineração que já se inicia sabendo ser infinita, porque sua mola propulsora é a questão, sabidamente insolúvel, que se faz nesse momento: "Que fazer (...)?".

Percebendo as duas estrofes unidas por essa questão, elas adquirem uma ligação cíclica e fica impossível dizer se seria a pergunta fruto da exaustão - que chega à impotência diante do bloqueio intransponível - ou se seria essa a pergunta fundamental, razão do começo, como espécie de pedra fundamental. Dessa forma, a mineração infinita termina por ser a resposta geradora da lírica, que se alimenta de, justamente, viver o bloqueio.

[...] O bloco central da obra de Drummond é, pois, regido por inquietudes poéticas que provêm uma das outras, cruzam-se e, parecendo derivar de um egotismo profundo, têm como consequência uma espécie de exposição mitológica da personalidade (CANDIDO, 2011, p. 70).

Essa perspectiva entrecruzada da primeira metade do poema parece ir de encontro a esse mesmo funcionamento da poética que se move entre reflexão e expressão, não sendo possível separar ou organizar seus elementos e relações isoladamente. $E$, uma vez que seus processos labirínticos parecem se mover e se costurar nessa grande situação aporética, não se sabe se a lírica do país bloqueado é princípio ou consequência do "não-escape".

"A derrota é então aquilo que o poeta se aproxima, e dela é que pode surgir uma beleza que não se fixa, que não está catalogada e em tudo dada e revelada." (BISCHOF, 2005. p. 134), adiantando, com esses dizeres da autora, o que se segue no poema; há, nessa espécie de Ode ao bloqueio, a experiência da negatividade e da derrota como terreno fértil, de onde algo novo pode surgir, pois essa é a questão fundamental dessa poesia enquanto poema-símbolo: o labirinto se desata. O nó da existência do inseto se desfaz quando nós já havíamos assumido seu estatuto de insolúvel, o que traz a necessidade de revertê-lo para outro estatuto, o do absolutamente inesperado e inexplicável ("oh razão, mistério"). Esse, mal tínhamos nos acostumado, atordoa a todos novamente e, à revelia das nossas recém-formadas expectativas, não se desata em escape, desbloqueio do caminho.

Muito ao contrário, o "rompimento" da situaçãobloqueio mal se revela e já nos lança ao inesperado novamente: ao ocorrer o desenlace, prontamente aguardávamos o outro lado; o que haveria, transposto o bloqueio, tão resistente à vã mineração? Eis que nos lança à certeza anterior: não há escape. E voltamos a ele em uma reafirmação ainda mais absoluta, pois mesmo superado o labirinto, não se chega à saída. É a certeza mais definitiva de que ela, de fato, nunca foi a questão, retornando mais uma vez a essa significaçãoemblema da lírica drummondiana.

A última estrofe de "Áporo" traz, no entanto, um novo elemento na sua construção de poema-emblema: "[...] Esse momento, vértice da peripécia, parece ser a mola mestra do poema. Narra-se ali, de maneira concisa, o instante crucial de um acontecimento, 0 nó, subitamente desfeito, de uma transformaçãa." (BISCHOF, 2005. p. 66). Opera, assim, a ressignificação 
de toda a lógica assumida na narrativa do impasse e somos colocados em um novo movimento, pois o labirinto, aparentemente intransponível, desata e não revela uma saída, mas se revela como essa mola propulsora da inesperada transformação.

[...] O momento positivo da negatividade do poeta diante do mundo opressivo, que é o instante de desfazimento do labirinto e do surgimento da flor, é também o momento da metamorfose que vai contra o princípio da nãocontradição. Oposto à pura lógica matemática ("antieuclidiana"), é perfeitamente coerente no entanto com uma lógica da imaginação, ragione poetica, mediante a qual a força do mito se casa à da história frente à mesma dificuldade: e se faz do impasse, mudança (ARRIGUCCl, 2002, p. 65).

Retomemos os versos que compõem esse momento final: "em verde, sozinha,/antieuclidiana,/uma orquídea forma-se.", eles são uma reafirmação da lógica poética drummondiana - e, talvez, da própria linguagem artística. $O$ eu lírico, sozinho, mergulhado na incompreensão, frente ao mundo que não se resolve, desata não o nó do bloqueio, mas o que atava ele e o mundo a uma mesma lógica. Diante dessa revelação, forma-se não a solução para os acontecimentos, mas um outro caminho: se ele e o mundo não compartilham da mesma lógica, ele, sim, pode se transformar.

Analisando mais detidamente o poema, vemos que o primeiro verso da última estrofe traz o verde na solidão do impasse que lhe deu surgimento, pois, se, comumente, é tomado como a cor da esperança, aqui é, como na natureza, a cor do início, da vida que vence o bloqueio e se impõe. É a transformação da trajetória do inseto para flor-inseto, flor-poema - e sabemos ser a imagem do nascimento da flor muito cara a Drummond uma saída, germina esse novo eu solitário, que surge no labirinto do mundo moderno e para além dele, com vida própria.

A seguir, no segundo verso, está a reafirmação do princípio da poética drummondiana: sua poesia surge, assim, solitária, perdida, aturdida no labirinto, mas por dele nascer, é o próprio labirinto transmutado, é a sua transformação de lógica matemática em lógica imagética. De modo que sua lírica surge justamente da subversão dos acontecimentos em matéria lírica: sem saída, a única possibilidade para sua poesia é transformar essa lógica estacada em outra, lutar entre acontecimentos e palavras até que sua lírica consiga se formar.

\section{[...] Olhar e recusa encontram-se aqui marcados por uma poética que tem na negatividade a possibilidade de expressão do seu sentimento do mundo, capaz de conter ainda, em alguns momentos esparsos (e representada pelo avesso), a rosa, violenta e meiga (como no poema "A Goeldi"), barrada - e mediada - pela escuridão que a circunda. (BISCHOF, 2005. p. 146)}

Assim sendo, a negatividade do impasse poderia condenar sua obra a um pessimismo persistente e crescente frente a essa modernidade que faz sua subjetividade, em labirinto, rodar eternamente em busca de uma compreensão, que nunca é alcançada. Mas, como afirma Bischof, a subjetividade labiríntica de Drummond estaca entre olhar e recusa, partida entre a experiência moderna e a arte reflexiva, e consegue subverter uma negatividade - que poderia assumir um tom fatalista - em motor pulsante de vida e resistência, que alimenta sua obra ao conseguir transformar a lógica estéril dos acontecimentos em libertação lírica.

O inseto-poeta, insignificante e impotente nas leis do mundo, se vive o desengano e a exaustão do impasse, 
afasta-se, desenlaça sua pena dos acontecimentos de forma a alimentar-se deles, mas não ser por eles determinado e soterrado-, transforma-se em importante revelação, orquídea, flor-poema. Por isso, esse poema se revela imprescindível para compreender a lírica drummondiana, é a narrativa primeira do procedimento poético em que se fundamenta a obra do poeta.

Ela não é, portanto, feita apenas do impasse, da pedra no meio do caminho: vida e escrita se perdem no labirinto, enfrentam o impasse hermético, terra bloqueada, até a exaustão e é, na impotência, que surge o escape, a reafirmação da saída inexistente, surgimento da transformação. É essa multiplicidade que está e permanece colocada, é ela a sua matéria. A orquídea, flor-poema vinda da mineração do inseto, é princípioafirmação de que é preciso transformar a pedra em poesia, bloqueio em história, caminho em memória através da experiência que, se percorre a dor, a desolação e a incompreensão, também faz brotar a consciência do mundo e de si, princípio de libertação e transformação.

\section{Referências bibliográficas}

ANDRADE, Mário de. Aspectos da literatura brasileira. São Paulo: Martins, s/d.

ARRIGUCCI JR., Davi. Coração partido. São Paulo: Cosac \& Naif, 2002.

BISCHOF, Betina. Razão da recusa: um estudo da poesia de Carlos Drummond de Andrade. São Paulo: Nankin, 2005.

CANDIDO, Antonio. Vários escritos. Rio de Janeiro: Ouro sobre Azul, 2011.

ANDRADE, Carlos Drummond de. A rosa do povo. São Paulo: Companhia das Letras, 2012.

Farewell. Rio de Janeiro: Record, 2007.

100 poemas: Carlos Drummond de Andrade. Belo Horizonte: Editora UFMG, 2002.

et al. Pau Brasil. São Paulo: DAEE, n. 13, ano III, 1986.

MERQUIOR, José Guilherme. Verso universo em Drummond. Rio de Janeiro: J. Olympio, Secretaria de Estado de Cultura, Ciência e Tecnologia, 1975.

PIGNATARI, Décio. Contracomunicação. Cotia: Ateliê Editorial, 2004.

SILVA, Luciana Bessa. Farewell: o último canto do poeta Carlos Drummond de Andrade. Disponível em: <https:// www.editorarealize.com.br/revistas/joinbr/trabalhos/TRABALHO_EVo81_MD1_SA72_ID2192_13092017100645.pdf >. Acesso em: 12 jun. 2018. 